\title{
ANALISIS PERBEDAAN TINGKAT PENGUNGKAPAN CORPORATE SOCIAL RESPONSIBILITY (CSR) DAN KINERJA KEUANGAN PERUSAHAAN PADA INDUSTRI HIGH-PROFILE DAN LOW-PROFILE
}

\author{
Sisilia Devina Permatasari \\ Supatmi \\ Fakultas Ekonomika dan Bisnis, Universitas Kristen Satya Wacana, Salatiga \\ patmie@,staff.uksw.edu
}

\begin{abstract}
This study aims to prove the difference in the level of disclosure of Corporate Social Responsibility (CSR) and financial performance among the industry's high-profile and lowprofile. This study also proved that if there is a relationship between the level of CSR and financial performance. Financial performance is measured using the Return On Equity (ROE) and Tobin's Q. The samples are 346 companies listed in Indonesia Stock Exchange (IDX) in 2012, where the industry as much as 167 high-profile and low-profile companies as much as 179 companies. The sampling method used is purposive sampling. The analyze used to test Mann-Whitney test first, while the second test using Spearman correlation test. The results of this study indicate that there are differences in the level of disclosure of CSR and financial performance as measured by Tobin's $Q$ between industrial high-profile and lowprofile, but did not differ when performance is measured by ROE. In addition, this study proves that there is a positive relationship between the level of CSR and financial performance as measured by ROE, but there is no relationship between the level of CSR and financial performance as measured by Tobin's $Q$.
\end{abstract}

Keywords : Corporate Social Responsibility Disclosure, ROE, Tobin's Q, high-profile and low-profile industries.

\section{Pendahuluan}

Kinerja keuangan merupakan salah satu faktor yang menjadi perhatian investor dalam membeli saham di pasar modal. Laporan keuangan yang dipublikasikan merupakan cerminan kinerja keuangan perusahaan. Selain itu, kinerja keuangan juga berarti sebagai penentu dalam mengukur keberhasilan suatu perusahaan dalam mencapai tujuan organisasi yaitu laba (Stoner et al. 1995:9). Selain laba (profit), ada hal yang sama pentingnya yaitu keberlangsungan atau sustainability (Sembiring 2005).

Keberlangsungan yang dilakukan perusahaan tidak dapat dipisahkan dari lingkungan eksternalnya, sehingga memunculkan konsep memunculkan konsep Corporate Social Responsibility (CSR) di mana komitmen perusahaan untuk memperhatikan aspek ekonomi, sosial dan lingkungan (triple bottom line). Corporate Social Responsibility (CSR) merupakan klaim agar perusahaan tak hanya beroperasi untuk kepentingan para pemegang saham (shareholders), tetapi juga untuk pihak stakeholders dalam praktik bisnis, yaitu para pekerja, komunitas lokal, pemerintah, LSM, konsumen, dan lingkungan (Dahlia dan Siregar 2008). Perusahaan tidak hanya mementingkan kesejahteraan shareholders, tetapi juga kepada stakeholders. Perusahaan yang menerapkan aktivitas CSR akan memperhatikan dampak dari kegiatan operasional perusahaan terhadap kondisi masyarakat, karyawan dan lingkungan. Dengan adanya konsep ini, maka pemerintah mengharapkan kerusakan lingkungan dapat diminimalkan. Penerapan CSR awalnya bersifat sukarela, akan tetapi dalam beberapa tahun ini telah dikeluarkan aturan bahwa perusahaan wajib melaksanakan CSR yang tertuang dalam 
PP No. 47 Tahun 2012 tentang tanggung jawab sosial dan lingkungan pada Perseroan Terbatas.

Kesadaran stakeholders meningkat terkait pentingnya informasi penerapan CSR demi keberlangsungan perusahaan sehingga mendorong perusahaan untuk mengungkapkan penerapan CSR di dalam laporan tahunan. Tingkat pengungkapan yang dilakukan oleh perusahaan ditemukan masih berbeda-beda. Hackston dan Milne (1996), Utomo (2000), dan Yap dan Widyaningdyah (2009) membuktikan bahwa peruhsaan pada industri high-profile akan memberikan informasi sosial lebih banyak dibandingkan perusahan low-profile. Menurut Robert (1992) dalam Gunawan dan Utami (2008), industri high-profile memiliki tingkat sensitivitas tinggi terhadap lingkungan sehingga mereka memiliki tekanan besar dari pihak luar untuk melakukan CSR sebagai bentuk dari pertanggungjawaban sosial perusahaan atas aktivitasnya yang berdampak buruk pada lingkungan. Sedangkan industri low-profile memiliki tingkat sensitivitas rendah terhadap lingkungan sehingga tekanan untuk melakukan CSR pun rendah. Adanya perbedaan karakteristik antara industri high-profile dan low-profile memiliki dampak yang berbeda dalam tingkat pengungkapan CSR.

Tingkat pengungkapan CSR yang berbeda pada industri high-profile dan low-profile memiliki dugaan bahwa kinerja keuangan perusahaan juga mengalami perbedaan. Ada beberapa peneliti yang telah menyelidiki pengaruh tingkat pengungkapan CSR terhadap kinerja perusahaan. Penelitian Dahlia dan Siregar (2008) dan Syahnaz (2012) menemukan tingkat pengungkapan CSR berpengaruh terhadap kinerja keuangan yang diproksikan dengan Return On Assets (ROA) dan Return On Equity (ROE), tetapi tidak berpengaruh terhadap CAR. Namun penelitian Cahyono dan Nur (2010), dan Yaparto dan Frisko (2013) membuktikan bahwa tingkat pengungkapan CSR tidak berpengaruh terhadap kinerja keuangan perusahaan yang diproksikan dengan ROE, ROA, Earning Per Share (EPS), dan Return Realisasi. Sedangkan penelitian Nurhayati dan Medyawati (2012) serta Muhammady dan Akbar (2012) membuktikan bahwa tingkat pengungkapan CSR tidak berpengaruh terhadap nilai perusahaan yang diproksikan dengan Tobin's Q. Namun penelitian Gunawan dan Utami (2008), Kusumadilaga (2010), dan Bidhari (2013) membuktikan bahwa tingkat pengungkapan CSR berpengaruh terhadap nilai perusahaan yang diproksikan dengan Tobin's Q.

Berdasarkan hasil penelitian terdahulu yang tidak konsisten sehingga penelitian ini ingin meneliti lebih lanjut untuk melihat adanya perbedaan tingkat pengungkapan CSR dan kinerja keuangan pada industri high-profile dan low-profile. Penelitian ini mereplikasi penelitian yang dilakukan Utomo (2000), dengan perbedaan penelitian ini akan membahas lebih lanjut perbedaan tingkat pengungkapan CSR dan kinerja keuangan antara industri highprofile dan low-profile di Indonesia pada tahun 2012, serta menguji hubungan antara tingkat pengungkapan CSR dengan kinerja keuangan. Kinerja keuangan diukur menggunakan ROE dan Tobin's Q sehingga dapat menunjukkan ukuran profitabilitas dari sudut pandang pemegang saham dan nilai perusahaan. Penelitian ini bermanfaat dalam pemberian informasi mengenai pentingnya tingkat pengungkapan CSR dan sebagai bahan pertimbangan dalam pembuatan kebijakan perusahaan di masa datang. Selain itu, penelitian ini memberikan informasi yang berguna bagi investor sebagai dasar pertimbangan dalam pengambilan keputusan.

\section{Tinjauan Literatur dan Perumusan Hipotesis}

\section{Pengungkapan Corporate Social Responsibility (CSR)}

Menurut Clarkson (1995) dalam buku karangan Lawrence dan James (2011: 7), teori stakeholder adalah sekelompok orang atau individu yang diidentifikasi dapat mempengaruhi 
atau dipengaruhi oleh kegiatan perusahaan. Perusahaan harus mampu menjaga hubungan baik dengan cara memenuhi kebutuhan dan keinginan stakeholder-nya (Lawrence dan James 2011: 7)). Salah satu cara untuk menjaga hubungan baik dengan stakeholder adalah dengan menerapkan CSR dan mengungkapkannya dalam laporan tahunan.

Menurut ISO 26000 mengenai Guidance on Social Responsibility (draft 3 2007), CSR adalah tanggung jawab sebuah organisasi terhadap dampak-dampak dari keputusankeputusan dan kegiatan-kegiatannya pada masyarakat dan lingkungan yang diwujudkan dalam bentuk perilaku transparan dan etis yang sejalan dengan pembangunan berkelanjutan dan kesejahteraan masyarakat, mempertimbangkan harapan pemangku kepentingan, sejalan dengan hukum yang ditetapkan dan norma-norma perilaku internasional, serta terintegrasi dengan organisasi secara menyeluruh. Aktivitas CSR yang dilakukan perusahaan butuh untuk diungkapkan. Pengungkapan tanggung jawab sosial perusahaan yang sering juga disebut sebagai social disclosure, corporate social reporting, social accounting merupakan proses pengkomunikasian dampak sosial dan lingkungan dari kegiatan ekonomi organisasi terhadap kelompok khusus yang berkepentingan dan terhadap masyarakat secara keseluruhan. Hal tersebut memperluas tanggung jawab organisasi (khususnya perusahaan), di luar peran tradisionalnya untuk menyediakan laporan keuangan kepada pemilik modal, khususnya pemegang saham. Perluasan tersebut dibuat dengan asumsi bahwa perusahaan mempunyai tanggung jawab yang lebih luas dibanding hanya mencari laba untuk pemegang saham (Gray et al. 1995).

Pengungkapan Corporate Social Responsibility terdiri dari beberapa komponen menurut Global Reporting Initiatives (GRI) tahun 2006. GRI merupakan standar yang pelaporan yang berstandar Internasional yang secara umum diterima dan diakui secara luas (William 2012). Komponen dan indikator untuk melihat pengungkapan Corporate Social Responsibility menurut GRI tahun 2006 dapat dibaca di lampiran.

\section{Tipe Industri High-Profile dan Low-Profile}

ISO 26000 menyediakan standar pedoman mengenai tanggung jawab sosial semua institusi. Pedoman tersebut ditujukan pada perusahaan yang memiliki tipe high-profile dan low-profile. Menurut Robert (1992) dalam Gunawan dan Utami (2008), tipe high-profile memiliki tingkat sensitivitas yang tinggi terhadap lingkungan, resiko politis dan tingkat persaingan yang tinggi. Industri ini merupakan perusahaan yang memperoleh sorotan masyarakat karena aktivitas operasinya memilki potensi untuk bersinggungan dengan kepentingan masyarakat luas. Ciri-cirinya adalah perusahaan yang memiliki tenaga kerja yang besar, proses produksinya mengeluarkan residu seperti limbah cair atau polusi dan bila perusahaan mengalami kelalaian dalam pengamanan produksi dan hasil produksi akan membawa akibat fatal bagi masyarakat dan lingkungan. Industri yang termasuk tipe highprofile antara lain perusahaan perminyakan dan pertambangan lain, kimia, hutan, kertas, otomotif, penerbangan, agrobisnis, tembakau dan rokok, produk makanan dan minuman, media dan komunikasi, energi (listrik), engineering, kesehatan serta transportasi dan pariwisata.

Di sisi lain, Robert (1992) dalam Gunawan dan Utami (2008) menyatakan bahwa tipe low-profile memiliki tingkat sensitivitas yang rendah terhadap lingkungan, resiko politis dan tingkat persaingan yang rendah. Industri ini merupakan perusahaan yang tidak terlalu mendapat sorotan luas dari masyarakat, saat operasi yang mereka lakukan mengalami kegagalan atau kesalahan pada aspek tertentu dalam proses atau hasil produksinya. Ciricirinya adalah perusahaan yang memiliki tenaga kerja yang lebih kecil, tidak memiliki sisa residu (seperti limbah) dan biasanya mendapat toleransi dari masyarakat dari kegagalan dalam produksi/ aktivitas kerja mereka. Industri tipe low-profile meliputi bangunan, 
keuangan dan perbankan, supplier peralatan medis, properti, retailer, tekstil dan produk tekstil, produk personal, dan produk rumah tangga.

\section{Perumusan Hipotesis}

\section{Tingkat Pengungkapan CSR pada Industri High-Profile dan Low-Profile}

Kepentingan stakeholder adalah hal yang diutamakan bagi perusahaan demi kelangsungan hidupnya. Perusahaan tidak hanya berfokus untuk memenuhi kepentingan pemegang saham, tetapi juga kepentingan stakeholder. Hal tersebut sesuai dengan teori stakeholder yaitu keberlangsungan perusahaan ditentukan oleh stakeholders, bukan shareholders (Gray et al. 1995). Pengungkapan CSR merupakan salah satu cara untuk menjaga hubungan baik antara perusahaan dan stakeholder-nya agar perusahaan tetap bertahan.

Tiap perusahaan memiliki tingkat pengungkapan CSR yang berbeda. Umumnya, perusahaan mengungkapkan aktivitas CSR karena ada tekanan dari lingkungan sekitar akibat aktivitas operasi yang dilakukan. Industri high-profile menurut Robert (1992) dalam Gunawan dan Utami (2008), memiliki tekanan yang besar dari lingkungannya sehingga akan mengungkapkan CSR lebih banyak dibandingkan industri low-profile yang memiliki tekanan yang lebih kecil. Di samping itu, resiko politis pada industri high-profile lebih tinggi daripada low-profile. Menurut UU No 23 tahun 1997 tentang Pengelolaan Lingkungan Hidup, industri high-profile berada di bawah pengawasan pemerintah yang cukup ketat, sedangkan lowprofile relatif rendah pengawasannya kecuali sektor perbankan. Muncul dugaan bahwa industri high-profile yang berada di bawah pengawasan pemerintah yang ketat akan mengungkapkan CSR lebih banyak daripada industri low-profile. Berdasarkan perbedaan karakterikstik tersebut menyebabkan tingkat pengungkapan CSR dalam laporan tahunan pada industri high-profile lebih banyak daripada industri low-profile.

Di sisi lain, pengungkapan CSR juga berkaitan dengan biaya pengungkapan. Ada kemungkinan industri low-profile lebih banyak mengungkapkan CSR dibandingkan highprofile ketika industri high-profile dikaitkan dengan biaya pengungkapan yang besar. Industri high-profile yang memiliki tingkat kompetisi yang tinggi antar perusahaan dihadapkan dengan biaya pengungkapan CSR yang besar, dimana untuk memenangkan kompetisi dibutuhkan biaya yang besar. Biaya operasional yang besar mengakibatkan industri ini tidak mampu untuk mengungkapkan CSR sehingga lebih banyak tingkat pengungkapan CSR pada industri low-profile dibandingkan high-profile. Penelitian Utomo (2000), Yap dan Widyaningdyah (2009), menemukan tingkat pengungkapan CSR pada perusahaan highprofile lebih tinggi daripada low-profile. Sehingga dapat diajukan hipotesis :

$\mathrm{H}_{1}$ : Ada perbedaan tingkat pengungkapan CSR pada industri high-profile dan low-profile

\section{Kinerja Keuangan pada Industri High-Profile dan Low-Profile}

Kinerja keuangan merupakan salah satu tolak ukur untuk mengukur keberhasilan suatu perusahaan. Tiap perusahaan memiliki kinerja keuangan yang berbeda. Begitu pula dengan perusahaan yang termasuk dalam industri high-profile dan low-profile yang diduga memiliki kinerja yang berbeda. Menurut Robert (1992) dalam Gunawan dan Utami (2008), karakteristik industri high-profile memiliki tingkat kompetisi yang tinggi daripada low-profile dimana mereka berlomba-lomba dan berusaha sekuat tenaga untuk meningkatkan penjualan dan laba perusahaan. Ketika industri high-profile mendapat tekanan yang besar, perusahaan akan berusaha untuk meningkatkan penjualan sehingga laba yang dihasilkan lebih tinggi dan pada akhirnya ROE meningkat. Namun, akibat tekanan besar yang dihadapi industri high- 
profile, maka akan menyebabkan beban yang tinggi pula sehingga laba yang dihasilkan tidak lebih tinggi, bahkan menjadi lebih rendah (Kieso et al. 2011: 148). Selain itu, ketika industri high-profile memiliki tekanan yang besar dan tingkat kompetisi yang tinggi, dapat

dimungkinkan akan memiliki respon pasar yang berbeda dimana dengan tekanan yang besar, maka respon pasar dapat tercermin dalam perubahan harga saham sehingga dapat mempengaruhi nilai Tobin's Q.

Adapun penelitian yang dilakukan oleh Susenohaji (2011) membuktikan bahwa terdapat perbedaaan kinerja keuangan yang diukur dengan ROE pada sektor agrobisnis, dan properti, sedangkan pada sektor pertambangan, industri kimia, industri makanan dan minuman, jasa dan perdagangan dan industri tekstil tidak memiliki perbedaan yang signifikan. Sehingga hipotesisi yang dapat diajukan :

$\mathrm{H}_{2}$ : Ada perbedaan kinerja keuangan pada industri high-profile dan low-profile

\section{Hubungan antara Tingkat Pengungkapan CSR dan Kinerja Keuangan pada Industri}

\section{High-Profile dan Low-Profile}

Muncul dugaan bahwa terdapat hubungan antara tingkat pengungkapan CSR dan kinerja keuangan. Argumen tersebut diperkuat dengan pernyataan bahwa perusahaan menggunakan sustainability reporting framework untuk mengkomunikasikan kinerja manajemen kepada para stakeholder dalam mencapai keuntungan jangka panjang (Finch (2005) dalam Dahlia dan Siregar (2008)). Perusahaan mengungkapkan CSR merupakan bentuk pertanggungjawaban perusahaan, dimana perusahaan tidak hanya berfokus pada aspek bisnis, tetapi juga pada aspek sosial. Diharapkan dengan banyak mengungkapkan CSR, masyarakat mengetahui bahwa perusahaan sadar tentang kepentingan sosial. Ditambah lagi, setelah masyarakat mengetahui bahwa perusahaan peduli terhadap lingkungan dan aspek sosial, maka dimungkinkan perusahaan juga peduli terhadap produknya. Dapat dikatakan bahwa semakin tinggi pengungkapan CSR akan memiliki relevansi semakin bagus pula kualitas produknya. Dengan produk berkualitas, maka masyarakat akan setia dengan produk perusahaan, dimana dalam jangka panjang akan meningkatkan pendapatan dan kinerja keuangan perusahaan pun akan meningkat.

Selain itu, dengan adanya pengungkapan CSR dapat meningkatkan reputasi perusahaan sehingga dapat memperbaiki hubungan dengan pihak bank, investor, pemerintahan, dan masyarakat (McGuire (1998) dalam Dahlia dan Siregar (2008)). Perbaikan hubungan yang terjadi tercermin pada peningkatan keuntungan perusahaan dan harga saham. Kenaikan harga saham merupakan indikasi meningkatnya nilai perusahaan. Semakin tinggi pengungkapan CSR, hal itu berarti perusahaan sadar akan tujuan jangka panjang, sehingga menunjukkan kemampuan going concern perusahaan di masa datang. Di sisi lain, kinerja keuangan yang baik sangat dibutuhkan oleh perusahaan untuk membiayai kegiatan dan pengungkapan CSR. Semakin baik kinerja keuangan perusahaan, maka semakin mampu perusahaan dalam membiayai pengungkapan CSR.

Berbagai penelitian yang menyelidiki hubungan tingkat pengungkapan CSR dan kinerja keuangan dapat diringkas sebagai berikut: 
Sisilia Devina Permatasari

Supatmi
Jurnal Manajemen Bisnis Indonesia

Vol. 3, Nomor 3, Juni 2016

Tabel 1. Review Penelitian Terdahulu

\begin{tabular}{|c|c|}
\hline Penelitian & Hasil \\
\hline Dahlia dan Siregar (2008) & $\begin{array}{l}\text { Tingkat pengungkapan CSR berpengaruh positif dan signifikan } \\
\text { terhadap ROE, namun tidak berpengaruh terhadap CAR } \\
\text { dengan menggunakan leverage, size, growth dan unexpected } \\
\text { return sebagai variabel control pada perusahaan di BEI tahun } \\
2005 \text { dan } 2006 \text {. }\end{array}$ \\
\hline Syahnaz (2012) & $\begin{array}{l}\text { Tingkat pengungkapan CSR berpengaruh terhadap ROA dan } \\
\text { ROE, tetapi tidak berpengaruh terhadap CAR pada Perusahaan } \\
\text { Perbankan pada tahun } 2009-2011 \text {. }\end{array}$ \\
\hline Cahyono dan Nur (2010) & $\begin{array}{l}\text { Tingkat pengungkapan CSR tidak berpengaruh terhadap ROE } \\
\text { dan CAR dengan kepemilikan asing sebagai variabel } \\
\text { moderating pada perusahaan manufaktur di BEI tahun 2006- } \\
2008 \text {. }\end{array}$ \\
\hline Yaparto dan Frisko (2013) & $\begin{array}{l}\text { Tingkat pengungkapan CSR tidak memiliki pengaruh terhadap } \\
\text { ROA, ROE, dan EPS pada sektor manufaktur di BEI tahun } \\
\text { 2010-2011. }\end{array}$ \\
\hline $\begin{array}{l}\text { Muhammady dan Akbar } \\
\text { (2012) }\end{array}$ & $\begin{array}{l}\text { Tingkat pengungkapan CSR tidak berpengaruh signifikan } \\
\text { terhadap Tobin's Q pada perusahaan manufaktur di BEI tahun } \\
\text { 2008-2010. }\end{array}$ \\
\hline $\begin{array}{l}\text { Nurhayati dan Medyawati } \\
\text { (2012) }\end{array}$ & $\begin{array}{l}\text { Tingkat pengungkapan CSR secara parsial tidak berpengaruh } \\
\text { dengan nilai perusahaan yang diproksikan dengan Tobin's Q } \\
\text { pada perusahaan yang terdaftar dalam LQ45 tahun 2009-2011. }\end{array}$ \\
\hline Gunawan dan Utami (2008) & $\begin{array}{l}\text { Tingkat pengungkapan CSR berpengaruh terhadap nilai } \\
\text { perusahaan yang diproksikan dengan Tobin's Q dengan } \\
\text { presentase pengelolaan kepemilikan dan jenis industri sebagai } \\
\text { variabel moderator pada perusahaan yang terdaftar di BEI pada } \\
\text { tahun 2005-2006. }\end{array}$ \\
\hline Kusumadilaga (2010) & $\begin{array}{l}\text { Tingkat pengungkapan CSR berpengaruh terhadap nilai } \\
\text { perusahaan yang diukur menggunakan Tobin's Q dengan } \\
\text { profitabilitas sebagai variabel moderating pada perusahaan } \\
\text { manufaktur di BEI tahun } 2006 \text { dan } 2008 \text {. }\end{array}$ \\
\hline Bidhari (2013) & $\begin{array}{l}\text { Tingkat pengungkapan CSR berpengaruh positif terhadap nilai } \\
\text { perusahaan yang diproksikan dengan Tobin's Q pada } \\
\text { perusahaan perbankan di Indonesia tahun } 2008-2010\end{array}$ \\
\hline
\end{tabular}

Sumber : Dari berbagai jurnal.

Berdasarkan penjelasan di atas, terdapat hasil penelitian tingkat pengungkapan CSR dan kinerja keuangan yang tidak konsisten. Maka peneliti ingin membuktikan kembali dengan hipotesis sebagai berikut:

$\mathrm{H}_{3}$ : Tingkat pengungkapan CSR memiliki hubungan dengan kinerja keuangan pada industri

high-profile dan low-profile.

\section{Metode Penelitian}

Penelitian ini menggunakan populasi perusahaan high-profile dan low -profile yang terdaftar di Bursa Efek Indonesia (BEI) pada tahun 2012. Pengambilan sampel ditentukan secara purposive sampling. Tabel 2 menunjukkan penentuan sampel penelitian: 
Tabel 2. Kriteria Penentuan Sampel

\begin{tabular}{llrrr}
\hline No & \multicolumn{1}{c}{ Kriteria Penentuan Sampel } & $\begin{array}{c}\text { Jumlah } \\
\text { High-Profile }\end{array}$ & $\begin{array}{c}\text { Jumlah } \\
\text { Low-Profile }\end{array}$ & Total \\
\hline 1. & Perusahaan yang terdaftar di BEI tahun 2012 & 260 & 212 & 472 \\
\hline 2. & $\begin{array}{l}\text { Perusahaan yang tidak mempublikasikan } \\
\text { Laporan Tahunan tahun 2012 di BEI }\end{array}$ & $(30)$ & $(12)$ & $(42)$ \\
\hline 3. & $\begin{array}{l}\text { Perusahaan yang tidak mempublikasikan } \\
\text { CSR dalam Laporan Tahunan pada tahun } \\
\text { 2012 }\end{array}$ & $(6)$ & $(7)$ & $(13)$ \\
\hline $\begin{array}{l}\text { Perusahaan yang memiliki data tidak lengkap } \\
\text { pada tahun 2012 }\end{array}$ & $(57)$ & $(14)$ & $(71)$ \\
\hline & & & & \\
\hline & & 167 & & \\
\hline
\end{tabular}

Kriteria perusahaan yang tidak mempublikasikan CSR yaitu ketika di dalam Laporan Tahunan tidak terdapat sama sekali item-item dari kriteria pengungkapan CSR menurut GRI. Selanjutnya, perusahaan yang tidak memiliki data lengkap meliputi perusahaan yang menggunakan satuan dollar dan tidak terdapatnya harga saham dalam Yahoo Finance.

Data yang digunakan dalam penelitian ini merupakan data sekunder berupa laporan tahunan dari industri high-profile dan low-profile di Bursa Efek Indonesia tahun 2012. Data tersebut berasal dari situs resmi di http://www.idx.co.id dan ICMD (Indonesian Capital Market Directory) serta bahan pendukung lainnya seperti data dari penelitian sebelumnya yang berhubungan dengan masalah yang diteliti. Selain itu juga menggunakan metode dokumentasi atau kutipan dari berbagai sumber.

Teknik analisis yang digunakan untuk pengujian hipotesis menggunakan Uji MannWhitney dan Spearmen Correlation. Sedangkan untuk variabel-variabel dalam penelitian ini adalah tingkat pengungkapan CSR perusahaan dan kinerja keuangan. CSR Disclosure diukur menggunakan indikator dari Global Reporting Initiative (GRI) dengan jumlah 79 item pengungkapan yang terdiri dari tiga kategori yaitu Economics Performance Indicators, Environmental Performance Indicators, dan Social Performance Indicators (lihat lampiran). Pendekatan untuk menghitung jumlah item yang diungkapkan oleh perusahaan menggunakan dikotomi (Dummy) yaitu setiap item yang mengungkapkan CSR diberi nilai 1 dan item yang tidak diungkapkan diberi nilai 0 (Sayekti dan Wondabio 2007). Sedangkan tingkat pengungkapan diukur dengan jumlah pengungkapan yang dilakukan dibagi dengan total pengungkapan maksimal (79 item).

Kinerja keuangan diukur menggunakan Return On Equity (ROE) dan Tobin's Q. Menurut Widayanti et al. (2006), ROE merupakan kemampuan dari modal sendiri untuk menghasilkan keuntungan bagi seluruh pemegang saham dengan membagi laba setelah pajak dengan total ekuitas. Sedangkan Tobin's Q menurut Smithers dan Wright (2000:37) dalam Gunawan dan Utami (2008), dihitung dengan rumus sebagai berikut :

$$
\mathrm{Q}=\frac{\mathrm{EMV}+\mathrm{D}}{\mathrm{EBV}+\mathrm{D}}
$$

Keterangan :

$\begin{array}{ll}\mathrm{Q} & =\text { Nilai Perusahaan } \\ \mathrm{EMV} & =\text { Nilai pasar ekuitas (harga saham akhir tahun } \mathrm{x} \text { jumlah saham beredar) } \\ \mathrm{EBV} & =\text { Nilai buku dari total ekuitas } \\ \mathrm{D}(\text { Debt }) & =\text { Nilai buku dari total hutang }\end{array}$


Sisilia Devina Permatasari

Supatmi
Jurnal Manajemen Bisnis Indonesia

Vol. 3, Nomor 3, Juni 2016

\section{Analisis Data dan Pembahasan Hasil}

\section{Statistik Deskriptif}

Berdasarkan tabel 3, nilai rata-rata tingkat pengungkapan CSR pada semua perusahaan di BEI pada tahun 2012 sebesar 0,41. Hasil ini lebih besar dibandingkan oleh penelitian Sayekti dan Wondabio (2007) yang mengambil sampel seluruh perusahaan di BEI yaitu sebesar 0,2 .

Tabel 3. Statistik Deskriptif

\begin{tabular}{|c|c|c|c|c|c|}
\hline Variabel Penelitian & $\mathbf{N}$ & Mean & Max & Min & St Dev \\
\hline CSR & 346 & 0,41 & 0,82 & 0,09 & 0,14 \\
\hline - High-Profile & 167 & 0,45 & 0,82 & 0,09 & 0,15 \\
\hline - Low-Profile & 179 & 0,36 & 0,75 & 0,11 & 0,12 \\
\hline $\mathrm{ROE}$ & 346 & 0,1 & 2,07 & $-3,97$ & 0,34 \\
\hline - High-Profile & 167 & 0,08 & 1,66 & $-3,97$ & 0,42 \\
\hline - Low-Profile & 179 & 0,12 & 2,07 & $-1,18$ & 0,25 \\
\hline TOBIN'S Q & 346 & 1,78 & 52,70 & 0,11 & 3,15 \\
\hline - High-Profile & 167 & 2,17 & 52,70 & 0,25 & 4,28 \\
\hline - Low-Profile & 179 & 1,42 & 14,10 & 0,11 & 1,37 \\
\hline
\end{tabular}

Sumber : Data diolah, 2014

Hal ini membuktikan bahwa semakin banyak perusahaan mengungkapkan aktivitas CSR yang dilakukannya. Selain itu, perusahaan juga semakin menyadari bahwa investor mulai menaruh perhatian pada aktivitas CSR yang dilakukan sehingga perusahaan mengungkapkan aktivitas tersebut dalam laporan tahunan demi memenuhi kebutuhan informasi bagi investor. Tabel tersebut juga menunjukkan rata-rata tingkat pengungkapan CSR pada industri high-profile lebih tinggi daripada industri low-profile yaitu 0,45 dan 0,36. Dari sisi kinerja keuangan, dihasilkan bahwa nilai rata-rata ROE pada industri low-profile lebih tinggi dibandingkan industri high-profile, sedangkan nilai rata-rata Tobin's Q industri high-profile lebih tinggi dari industri low-profile.

\section{Pengujian Hipotesis}

\section{Tingkat Pengungkapan CSR pada Industri High-Profile dan Low-Profile}

Berdasarkan tabel 4, hasil penelitian ini membuktikan bahwa hipotesis pertama diterima yaitu terdapat perbedaan tingkat pengungkapan CSR yang signifikan pada industri high-profile dan low-profile tahun 2012.

Tabel 4. Hasil Analisis Uji Beda Tingkat Pengungkapan CSR

\begin{tabular}{lr}
\hline \multicolumn{2}{c}{${\text { Test } \text { Statistics }^{a}}^{a}$} \\
\hline Mann-Whitney U & CSR \\
Wilcoxon W & $2.686 \mathrm{E} 3$ \\
Z & $-580 \mathrm{E} 4$ \\
Asymp. Sig. (2-tailed) & .061 \\
\hline a. Grouping Variable: KODING_CSR & .000 \\
\hline
\end{tabular}

Sumber : Diolah dari SPSS, 2014 
Hal ini juga sejalan dengan temuan dalam statistik deskriptif rata-rata tingkat pengungkapan CSR dalam industri high-profile lebih tinggi daripada low-profile. Perbedaan tingkat pengungkapan CSR antar kedua kelompok industri tersebut terjadi sejalan dengan pendapat Robert (1992) dalam Gunawan dan Utami (2008), terkait dengan karakteristik dari kedua industri tersebut yang berbeda. Industri high-profile memiliki tekanan yang lebih besar untuk mengungkapkan CSR akibat aktivitas bisnisnya memiliki tingkat sensitivitas yang tinggi terhadap lingkungan. Selain itu, industri high-profile mendapat sorotan lebih luas daripada industri low-profile karena aktivitasnya lebih bersinggungan dengan kepentingan masyarakat. Ditambah lagi, pada industri high-profile apabila perusahaan mengalami kelalaian dalam pengamanan produksi dan hasil produksi akan membawa akibat fatal bagi masyarakat dan lingkungan. Hasil penelitian ini sejalan dengan penelitian yang dilakukan oleh Utomo (2000) dan Yap dan Widyaningdyah (2009) yang membuktikan bahwa tingkat pengungkapan CSR pada industri high-profile lebih tinggi daripada industri low-profile.

\section{Kinerja Keuangan pada Industri High-Profile dan Low-Profile}

Berdasarkan tabel 5, hasil pengujian ini menemukan bahwa ada perbedaan kinerja keuangan yang diukur dengan Tobin's Q antara industri high profile dan low profile, namun tidak ada perbedaan jika kinerja keuangan diukur dengan ROE.

Tabel 5. Hasil Analisis Uji Beda Kinerja Keuangan

\begin{tabular}{lrr}
\hline \multicolumn{3}{c}{ Test Statistics $^{\mathbf{a}}$} \\
\hline \multicolumn{1}{c}{ TOBIN } & \multicolumn{1}{c}{ ROE } \\
\hline Mann-Whitney U & $1.166 \mathrm{E} 4$ & $1.489 \mathrm{E} 4$ \\
Wilcoxon W & $2.778 \mathrm{E} 4$ & $2.892 \mathrm{E} 4$ \\
Z & -3.530 & -.059 \\
Asymp. Sig. (2-tailed) & .000 & .953 \\
a. Grouping Variable: KODING_ROE & & \\
\hline
\end{tabular}

Sumber: Diolah dari SPSS, 2014

Hal tersebut berarti bahwa dari sudut pandang pasar, dalam hal ini investor, industri high profile dengan tingkat pengungkapan CSR-nya yang tinggi dianggap juga memiliki keberlangsungan hidup yang lebih baik daripada industri low profile. Meski risiko politis yang dihadapai industri high profile tinggi, namun industri ini ditopang oleh pihak pemerintah sehingga dapat dikatakan memiliki kemampuan going concern yang baik, mengingat industri ini banyak terkait dengan pengeloaan sumber daya alam.

Namun dari sudut pandang kinerja profitabilitas jangka pendek, yaitu ROE, antara industri high profile dan low profile tidak terdapat perbedaan. Hal tersebut diduga disebabkan tingginya tingkat penjualan diiringi oleh tingginya beban yang dihasilkan untuk industri highprofile. Menurut Robert (1992) dalam Gunawan dan Utami (2008), industri high-profile memiliki tingkat kompetisi yang tinggi sehingga perusahaan berusaha meningkatkan penjualan dengan meningkatkan biaya iklan, pada akhirnya laba belum tentu meningkat. Di sisi lain, ada banyak faktor yang mempengaruhi komponen laba. Pembagian perusahaan menjadi dua kelompok industri yaitu high-profile dan low-profile merupakan pembagian berdasarkan kegiatan operasi perusahaan (Robert dalam Gunawan dan Utami (2008)). Laba yang bagus tidak hanya selalu dilihat dari tingkat persaingan, tetapi juga dapat terjadi karena kinerja perusahaan itu memang bagus disamping laba tersebut dapat di-manage. Apabila industri low-profile memiliki laba tinggi dan kinerja yang bagus, maka tingkat ROE pada industri ini tetap lebih bagus daripada industri high-profile. Hasil statistik penelitian ini pun menyatakan bahwa kinerja keuangan industri low-profile lebih tinggi daripada high-profile. 
Komponen laba bersih termasuk laba operasi dan laba diluar usaha (Kieso et al. 2011: 148), sehingga kemungkinan laba di luar operasi pada industri low-profile lebih tinggi dari laba usaha sehingga dapat menghasilkan laba yang tinggi. Sebagai contoh adalah sektor perbankan yang memiliki berbagai produk yang ditawarkan di luar kegiatan operasi utamanya, misalkan asuransi. Kemungkinan pendapatan asuransi lebih tinggi daripada pendapatan utama perbankan. Hasil penelitian ini sejalan oleh hasil penelitian Susenohaji (2011), dimana secara garis besar kinerja keuangan yang diukur dengan ROE tidak memiliki perbedaan yang signifikan antara industri high-profile dan low-profile.

\section{Hubungan Tingkat Pengungkapan CSR dan Kinerja Keuangan}

Berdasarkan tabel 6 ditemukan bahwa tingkat pengungkapan CSR berhubungan positif dengan kinerja keuangan yang dilihat dari ROE, namun tidak berhubungan dengan Tobins'Q.

Tabel 6. Hasil Analisis Uji Korelasi Tingkat Pengungkapan CSR dan Kinerja

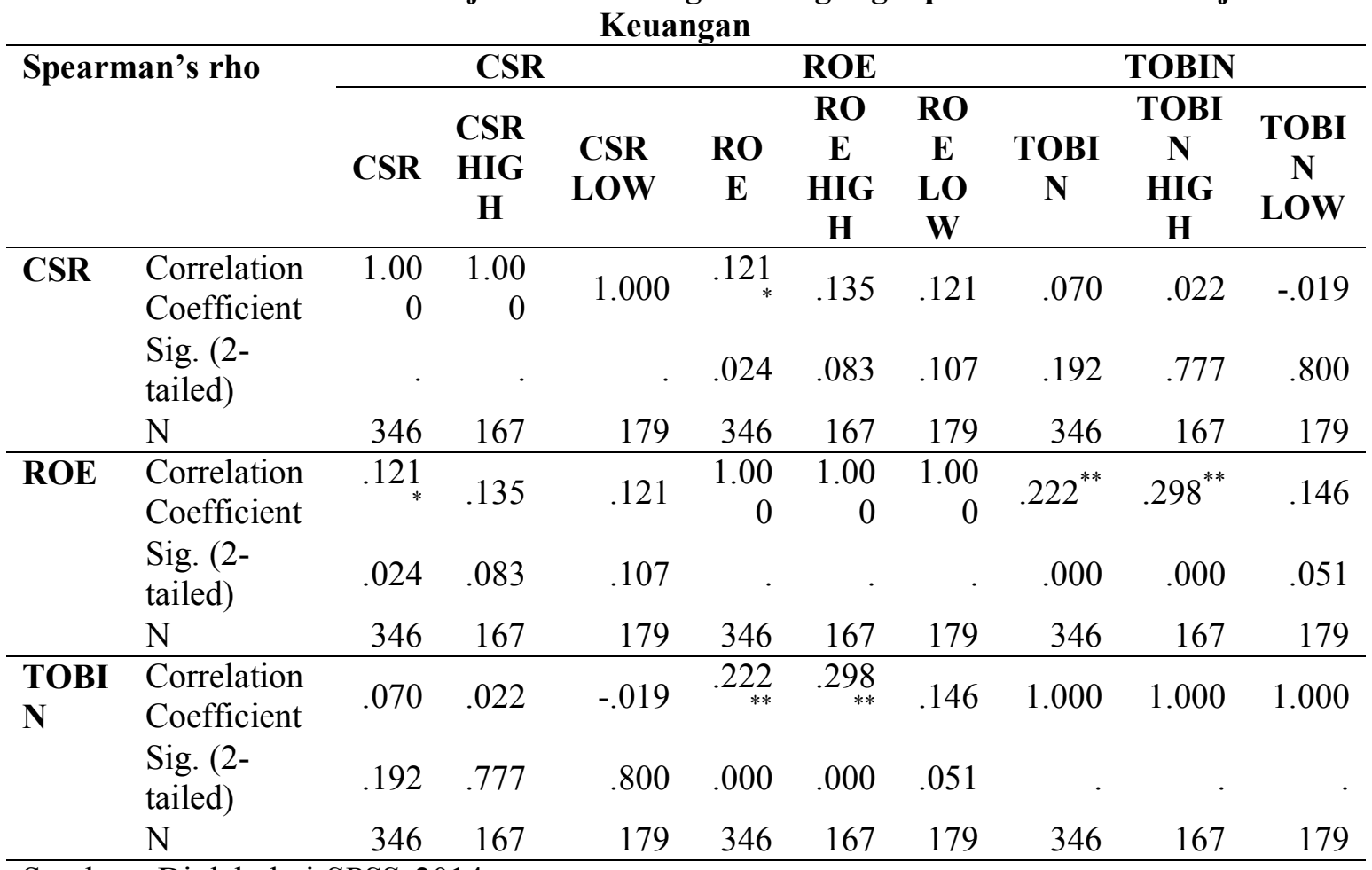

Sumber : Diolah dari SPSS, 2014

Semakin tinggi tingkat pengungkapan CSR, menunjukkan bahwa perusahaan sadar akan kepentingan sosial dan kualitas produknya, sehingga dapat dikatakan perusahaan dengan tingkat pengungkapan CSR yang tinggi, produknya semakin berkualitas. Masyarakat akan dengan setia membeli produk yang berkualitas, sehingga akan meningkatkan penjualan dan laba perusahaan dalam jangka panjang. Selain itu, perusahaan yang memiliki kinerja keuangan yang baik, akan mampu untuk mengungkapkan CSR sehingga semakin tinggi tingkat pengungkapan CSR-nya.

Namun, ketika dikaitkan dengan pengelompokan industri, ditemukan bahwa tidak ada hubungan antara tingkat pengungkapan CSR dengan kinerja keuangan yang diukur dengan ROE maupun Tobin's Q baik pada industri high-profile dan low-profile. Hal ini berarti bahwa 
tingkat pengungkapan CSR tidak berhubungan dengan tinggi rendahnya ROE dan Tobin's Q. Diduga kinerja ROE dan Tobin's Q dipengaruhi oleh variabel lain, dimana tingkat pengungkapan CSR dikatakan manfaat yang diperoleh masih belum jelas dan pengungkapan CSR sendiri masih bersifat sukarela sehingga kinerja keuangan yang diukur dengan ROE dan reaksi pasar yang tercermin pada harga saham yang diukur dengan Tobin's Q tidak memperoleh dampaknya. Harga saham relatif tetap menunjukkan bahwa nilai perusahaan tidak berkembang. Perbedaan Tobin's Q dalam perusahaan belum tentu disebabkan oleh CSR karena ternyata tingkat pengungkapan CSR dan Tobin's Q tidak berhubungan.

Hasil penelitian ini sejalan dengan penelitian yang dilakukan oleh Dahlia dan Siregar (2008) dan Syahnaz (2012) yang membuktikan bahwa tingkat pengungkapan CSR dan kinerja keuangan yang diukur dengan ROE memiliki hubungan yang signifikan. Selain itu, penelitian ini juga diperkuat oleh penelitian Muhammady dan Akbar (2012) dan Nurhayati dan Medyawati (2012) yang membuktikan bahwa tingkat pengungkapan CSR dan kinerja keuangan yang diukur dengan Tobin's Q tidak memiliki hubungan yang signifikan.

\section{Penutup}

\section{Kesimpulan}

Berdasarkan hasil analisis di atas, dapat disimpulkan bahwa terdapat perbedaan antara tingkat pengungkapan CSR dan kinerja keuangan yang diukur dengan Tobin's Q antara industri high-profile dan low-profile, tetapi tidak terdapat perbedaan kinerja keuangan yang diukur dengan ROE. Penelitian ini juga membuktikan terdapat hubungan positif antara tingkat pengungkapan CSR dan kinerja keuangan yang diukur dengan ROE, tetapi tidak terdapat hubungan antara tingkat pengungkapan CSR dan kinerja keuangan yang diukur dengan Tobin's Q. Antara industri high-profile dan low-profile, ditemukan juga tidak terdapat hubungan antara tingkat pengungkapan CSR dan kinerja keuangan, baik diukur dengan ROE dan Tobin's Q.

Hasil penelitian ini dapat memberi gambaran bagi perusahaan bahwa tingkat pengungkapan CSR merupakan salah satu pertimbangan penting bagi investor dalam membuat keputusan investasi. Oleh karena itu, semakin banyak perusahaan mengungkapkan CSR, maka semakin baik perusahaan di mata investor. Informasi tingkat pengungkapan CSR dapat menjadi bahan pertimbangan dalam menentukan kebijakan di bidang sosial di masa depan sehingga dapat membawa keuntungan baik bagi perusahaan, masyarakat, dan lingkungan. Investor akan lebih diuntungkan bila berinvestasi pada industri high-profile karena industri ini lebih direspon pasar dan memiliki tekanan yang besar untuk melaksanakan dan mengungkapkan CSR sehingga dampak dari tingkat pengungkapan CSR secara berkelanjutan akan memberi manfaat jangka panjang bagi perusahaan. Manfaat tersebut dapat meningkatkan profitabilitas perusahaan di masa depan sehingga dapat dikatakan perusahaan memiliki going concern yang baik.

\section{Keterbatasan Penelitian dan Saran Penelitian Mendatang}

Penelitian ini memiliki beberapa keterbatasan yang dihadapi yaitu ada unsur subjektifitas dalam penilaian tingkat pengungkapan CSR, serta sedikit subjektifitas pada pengelompokan beberapa kelompok di ICMD yaitu untuk sektor Holding and Other Investment dan Others. Selain itu, penelitian ini tidak menunjukkan dampak berkelanjutan dari tingkat pengungkapan CSR karena hanya dilihat dalam jangka waktu penelitian setahun.

Dengan adanya keterbatasan dalam penelitian ini, maka ada beberapa saran untuk penelitian mendatang. Pertama, menambah periode penelitian sehingga dampak dari tingkat 
pengungkapan CSR secara berkelanjutan dapat lebih terlihat misalnya dalam rentang 3 tahun. Kedua, mempertimbangkan penyempurnaan daftar penilaian tingkat pengungkapan CSR sehingga alat tersebut dapat menghasilkan informasi yang sesuai kondisi saat ini dan lebih teliti. Ketiga, penggunaan informasi lain selain dari laporan tahunan sebagai dasar menilai tingkat pengungkapan CSR perusahaan. Contohnya yaitu sustainability reporting (Laporan Keberlanjutan) dan survei dari badan organisasi tertentu mengenai aktivitas CSR.

\section{Daftar Pustaka}

Bidhari, S, C. 2013. Effect of Corporate Social Responsibility Information Disclosure on Financial Performance and Firm Value in Banking Industry Listed at Indonesia Stock Exchange. Faculty of Economics and Business Brawijaya University. http://www.iiste.org/Journals/index.php/EJBM/article/viewFile/6642/6786 (diakses 11 Januari 2014, 6:15 PM)

Cahyono, Budi dan Etna Nur. 2010. Pengaruh Corporate Social Responsibility terhadap Kinerja Perusahaan dengan Kepemilikan Asing Sebagai Variabel Moderating. Fakultas Ekonomi Universitas Diponegoro Semarang. http://eprints.undip.ac.id/26643/1/SKRIPSI(r).pdf (diakses 11 Januari 2014, 8:13 PM)

Dahlia, Lely dan Sylvia Veronica Siregar. 2008. Pengaruh Corporate Social Responsibility terhadap Kinerja Perusahaan. Jurnal disajikan dalam Simposium Nasional Akuntansi XI, Pontianak.

Gray R, Kouhy and Lavers. 1995. Corporate social and environmental reporting: A review of the literature and a longitudinal study of UK disclosure. Accounting, Auditing \& Accountability Journal 8 (2): 78-101. http://www.emeraldinsight.com/journals.htm?articleid=869644 (diakses 13 Januari 2014, 6:30 PM)

Gunawan, Barbara dan Suharti Sri Utami. 2008. Peranan Corporate Social Responsibility dalam Nilai Perusahaan. Fakultas Ekonomi Universitas Muhammadiyah Yogyakarta. http://publikasiilmiah.ums.ac.id/bitstream/handle/123456789/843/07Barbara\%20_174-185 .pdf?sequence=1 (diakses 13 Januari 2014, 7:35 PM).

Hackston, David and Markus J. Milne. 1996. Some Determinants of Social and Environmental Disclosure in New Zealand Companies. Accounting, Auditing and Accountability Journal. Vol. 9, No. 1, p. 77-108. http://www.emeraldinsight.com/journals.htm?articleid=1509110 (diakses 13 Januari 2014, 8:10 PM).

Kieso, Donald E, Jerry J. Weygandt, and Terry D. Warfield. 2011. Intermediate Accounting Vol 1 IFRS Edition. United States of America: Graphics.

Kusumadilaga, Rimba. 2010. Pengaruh Corporate Social Responsibility terhadap Nilai Perusahaan dengan Profitabilitas sebagai Variabel Moderating. Fakultas Ekonomi Universitas Diponegoro Semarang. http://eprints.undip.ac.id/22572/1/SKRIPSI_Rimba_Kusumadilaga.PDF (diakses 14 Januari 2014, 7:30 PM). 
Lawrence, Anne T. dan James Weber. 2011. Business and Society Stakeholders, Ethics, Public Policy, Thirteenth Edition. New York: McGraw-Hill.

Muhammady, El dan Faddly Akbar. 2012. Pengaruh Kinerja Keuangan dan Corporate Social Responsibility Terhadap Nilai Perusahaan Pada Perusahaan Manufaktur Yang Terdaftar di BEI. Fakultas Ekonomi Universitas Gunadarma.

http://publication.gunadarma.ac.id/bitstream/123456789/6167/1/JURNAL\%20SKRIP

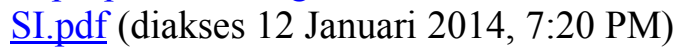

Nurhayati, Miranty dan Henny Medyawati. 2012. Analisis Pengaruh Kinerja Keuangan, Good Corporate Governance, dan Corporate Social Responsibility terhadap Nilai Perusahaan yang Terdaftar dalam LQ45 pada tahun 2009-2011. Fakultas Ekonomi Universitas Gunadarma. http://publication.gunadarma.ac.id/bitstream/123456789/5532/1/JurnalOK.pdf (diakses 14 Januari 2014, 7:33 PM).

Sayekti, Yosefa dan Ludovicus Sensi Wondabio. 2007. Pengaruh CSR Disclosure terhadap Earning Response Coefficient (Suatu Studi Empiris pada Perusahaan yang terdaftar di Bursa Efek Jakarta). Jurnal disajikan dalam Simposium Nasional Akuntansi X, Makassar.

Sembiring, Eddy Rismanda. 2005. Karakteristik Perusahaan dan Pengungkapan Tanggung Jawab Sosial. Jurnal disajikan dalam Simposium Nasional Akuntansi VIII, Solo.

Stoner, James A. F., Edward Freeman, dan Daniel R. Gilbert. 1995. Management, Sixth Edition. United States of America: Prentice Hall.

Susenohaji. 2011. Analisis Kinerja Keuangan Perusahaan Atas Ungkapan (Disclosure) Tanggung Jawab Lingkungan Perusahaan (Studi Empiris Penerapan Regulasi pada Perusahaan Go-Publik di Indonesia.) http://www.academia.edu/6406277/Judul_Analisis_Kinerja_Keuangan_Perusahaan_A tas_Ungkapan_Disclosure Tanggungjawab_Lingkungan_Perusahaan_Studi_Empiris Penerapan Regulasi pada_Perusahaan_Go-Publik_di_Indonesia (diakses tanggal 16 Juli 2014, 16:00 PM)

Syahnaz, Melisa. 2012. Pengaruh Corporate Social Responsibility terhadap Kinerja Keuangan Perusahaan Perbankan. Fakultas Ekonomi dan Bisnis Universitas Brawijaya. http://jimfeb.ub.ac.id/index.php/jimfeb/article/download/352/299 (diakses 23 Januari 2014, 7:45 PM).

Utomo, Muhammad Muslim. 2000. Praktek Pengungkapan Sosial pada Laporan Tahunan Perusahaan di Indonesia (Studi Perbandingan antara Perusahaan High-Profile dan Low-Profile). Jurnal disajikan dalam Simposium Nasional Akuntansi IV, Bandung.

Widayanti, Rita, Henny Ekawati, Apriani Dorkas Rambu Atahau, Usil Sis Sucahyo, dan Maria Rio Rita. 2006. Manajemen Keuangan. Fakultas Ekonomi Universitas Kristen Satya Wacana, Salatiga. 
William. 2012. Pengaruh Pengungkapan Corporate Social Responsibility berdasarkan Pedoman Global Reporting Initiative terhadap Nilai Perusahaan. Fakultas Ekonomi Universitas Indonesia. www.ui.ac.id (diakses 26 September 2014, 15:25 PM)

Yaparto, Marissa dan Dianne Frisko. 2013. Pengaruh Corporate Social Responsibility terhadap Kinerja Keuangan pada Sektor Manufaktur yang terdaftar di Bursa Efek Indonesia pada Periode 2010-2011. Fakultas Bisnis dan Ekonomika Universitas Surabaya. https://journal.ubaya.ac.id/index.php/jimus/article/viewFile/111/91 (diakses 25 Januari 2014, 9:15 PM).

Yap, Raldy dan Agnes Widyaningdyah. 2009. Pengungkapan Pertanggungjawaban Sosial pada Laporan Tahunan Perusahaan Yang Go Public di Bursa Efek Indonesia (Studi Empiris atas Perusahan High dan Low Profile). Universitas Katolik Widya Mandala. http://download.portalgaruda.org/article.php?article=18498\&val=1144\&title (diakses 23 Januari 2014, 8:40 PM). www.globalreporting.org (diakses tanggal 2 Februari 2014, 7:30 PM)

\section{Lampiran 1}

\section{Daftar Item Pengungkapan CSR menurut GLOBAL REPORTING INITIATIVE (GRI)}

\section{Lingkungan}

1. Pengendalian polusi kegiatan operasi, pengeluaran riset dan pengembangan untuk mengurangi polusi.

2. Operasi perusahaan tidak mengakibatkan polusi atau memenuhi ketentuan hukum dan peraturan polusi.

3. Pernyataan yang menunjukkan bahwa polusi operasi telah atau akan dikurangi.

4. Pencegahan atau perbaikan kerusakan lingkungan akibat pengelolaan sumber alam, misalnya reklamasi daratan atau reboisasi.

5. Konservasi sumber alam, misalnya mendaur ulang kaca, besi, minyak, air dan kertas.

6. Penggunaan material daur ulang

7. Menerima penghargaan berkaitan dengan program lingkungan yang dibuat perusahaan.

8. Merancang fasilitas yang harmonis dengan lingkungan.

9. Kontribusi dalam seni yang bertujuan untuk memperindah lingkungan.

10. Kontribusi dalam pemugaran bangunan sejarah.

11. Pengelolaan limbah.

12. Riset mengenai pengelolaan limbah.

13. Mempelajari dampak lingkungan untuk memonitor dampak lingkungan perusahaan.

14. Perlindungan lingkungan hidup.

\section{Energi}

15. Menggunakan energi secara lebih efisien dalam kegiatan operasi.

16. Memanfaatkan barang bekas untuk memproduksi energi.

17. Penghematan energi sebagai hasil produk daur ulang.

18. Membahas upaya perusahaan dalam mengurangi konsumsi energi.

19. Peningkatan efisiensi energi dan produk.

20. Riset yang mengarah pada peningkatan efisiensi energi dari produk.

21. Mengungkapkan kebijakan energi perusahaan. 


\section{Kesehatan dan Keselamatan Kerja}

22. Mengurangi polusi, iritasi, atau resiko dalam lingkungan kerja.

23. Mempromosikan keselamatan tenaga kerja dan kesehatan fisik atau mental.

24. Mengungkapkan statistik kecelakaan kerja.

25. Mentaati peraturan standar kesehatan dengan keselamatan kerja.

26. Menerima penghargaan berkaitan dengan keselamatan kerja.

27. Menetapkan suatu komite keselamatan kerja.

28. Melaksanakan riset untuk meningkatkan keselamatan kerja.

29. Mengungkapkan pelayanan kesehatan tenaga kerja.

\section{Lain-lain Tentang Tenaga Kerja}

30. Perekrutan atau memanfaatkan tenaga kerja wanita / orang cacat.

31. Mengungkapkan persentase/jumlah tenaga kerja wanita / orang cacat dalam tingkat manajerial.

32. Mengungkapkan tujuan penggunaan tenaga kerja wanita / orang cacat dalam pekerjaan.

33. Program untuk kemajuan tenaga kerja wanita / orang cacat.

34. Pelatihan tenaga kerja melalui program tertentu di tempat kerja.

35. Memberikan bantuan keuangan pada tenaga kerja dalam bidang pendidikan.

36. Mendirikan suatu pusat pelatihan tenaga kerja.

37. Mengungkapkan bantuan atau bimbingan untuk tenaga kerja yang dalam proses mengundurkan diri atau yang telah membuat kesalahan.

38. Mengungkapkan perencanaan kepemilikan rumah karyawan.

39. Mengungkapkan fasilitas untuk aktivitas rekreasi.

40. Pengungkapan persentase gaji untuk pensiun.

41. Mengungkapkan kebijakan penggajian dalam perusahaan.

42. Mengungkapkan jumlah tenaga kerja dalam perusahaan.

43. Mengungkapkan tingkatan manajerial yang ada.

44. Mengungkapkan disposisi staff dimana staff ditempatkan.

45. Mengungkapkan jumlah staff, masa kerja dan kelompok usia mereka.

46. Mengungkapkan statistik tenaga kerja, misalnya penjualan per tenaga kerja.

47. Mengungkapkan kualifikasi tenaga kerja yang direkrut.

48. Mengungkapkan rencana kepemilikan saham oleh tenaga kerja.

49. Mengungkapkan rencana pembagian keuntungan lain.

50. Mengungkapkan informasi hubungan manajemen dengan tenaga kerja dalam meningkatkan keputusan dan motivasi kerja.

51. Mengungkapkan informasi stabilitas pekerjaan tenaga kerja dan masa depan perusahaan.

52. Membuat laporan tenaga kerja yang terpisah.

53. Melaporkan hubungan perusahaan dengan serikat buruh.

54. Melaporkan gangguan dan aksi tenaga kerja.

55. Mengungkapkan informasi bagaimana aksi tenaga kerja dinegosiasikan.

56. Peningkatan kondisi kerja secara umum.

57. Informasi reorganisasi perusahaan yang mempengaruhi tenaga kerja.

58. Informasi dan statistik perputaran tenaga kerja.

Produk

59. Pengungkapan informasi pengembangan produk perusahaan, termasuk pengemasan. 
60. Gambaran pengeluaran riset dan pengembangan produk.

61. Pengungkapan informasi proyek riset perusahaan untuk memperbaiki produk.

62. Pengungkapan bahwa produk memenuhi standar keselamatan.

63. Membuat produk lebih aman untuk konsumen.

64. Melaksanakan riset atas tingkat keselamatan produk perusahaan.

65. Pengungkapan peningkatan kebersihan / kesehatan dalam pengolahan dan penyiapan produk.

66. Pengungkapan informasi atas keselamatan produk perusahaan.

67. Pengungkapan informasi mutu produk yang dicerminkan dalam penerimaan penghargaan.

68. Informasi yang dapat diverifikasi bahwa mutu produk telah meningkat (misalnya, ISO 9000).

Keterlibatan Masyarakat

69. Sumbangan tunai, produk, pelayanan untuk mendukung aktivitas masyarakat, pendidikan, dan seni.

70. Tenaga kerja paruh waktu (part-time employment) dari mahasiswa/pelajar.

71. Sebagai sponsor untuk proyek kesehatan masyarakat.

72. Membantu riset media.

73. Sebagai sponsor untuk konferensi pendidikan, seminar atau pameran seni.

74. Membiayai program beasiswa.

75. Membuka fasilitas perusahaan untuk masyarakat.

76. Mensponsori kampanye nasional.

77. Mendukung pengembangan industri lokal.

Umum

78. Pengungkapan tujuan. Kebijakan perusahaan secara umum berkaitan dengan tanggung jawab sosial perusahaan kepada masyarakat.

79. Informasi hubungan dengan tanggung jawab sosial perusahaan selain yang disebut di atas. 